Our Nature (2009) 7:203-206

\title{
Antibiotic Profiling of Heavy Metal Resistant Bacterial Isolates from the Effluent of a Garment Industry in Lalitpur, Nepal
}

\author{
M. Sharma ${ }^{1^{*}}$ and H.P. Thapaliya ${ }^{2}$ \\ ${ }^{1}$ Department of Microbiology, St. Xavier's College, Kathmandu, Nepal \\ ${ }^{2}$ Department of Zoology, Tri-Chandra Multiple College, Kathmandu, Nepal \\ *E-mail:mohanmicrobio@gmail.com
}

Received: 21.01.2009, Accepted: 09.04.2009

\begin{abstract}
Heavy metal resistant bacterial isolates from the effluent in a garment industry site were examined to assess their resistance towards multiple antibiotics. Heavy metal resistance property has been found to enhance the antibiotic resistance ability of microorganisms. Isolation of the heavy metal resistant organis ms was done in media containing salts of heavy metals. Organisms were identified belonging to the genera Bacillus, Corynebacterium, Lactobacillus, Aeromonas and Enterococcus. Bacterial isolates were tested for their sensitivity to seven common antibiotics (penicillin, tetracycline, erythromycin, chloramphenicol, gentamicin, vancomycin and cotrimoxazole) using Kirby-Bauer technique. Isolates were found to be resistant to multiple antibiotics but all the isolates were sensitive to gentamicin. The data of our study indicates that metal pollution of the environment is the cause of heavy metal resistance isolates and hence antibiotic resistance.
\end{abstract}

Key words: Heavy metal, effluent, antibiotics, resistance, Bacteria, pollution.

\section{Introduction}

Increased incidence of industrialization in the urban as well as semi urban localities has led to the improper disposal of the wastes to the water bodies. The water disposed from the industrial activities like mining, tanning, dyeing and washing are the good sources of heavy metals. The study was conducted with the view of isolating heavy metal resistant bacteria from the waste disposal site of the garment industry. The sample was collected from the dyeing unit drainage site, a suitable habitat for the metal resistant isolates.

Presence of high concentration of toxic heavy metals in waste water leads to the contamination of the receiving water bodies and deleterious impact on aquatic life (Moten and Rehman, 1998).

Microorganisms resistant to both antibiotics and metals have been isolated from infections treated with metal-based antimicrobial agents (McHugh et al., 1975), and various metal-contaminated environments such as estuaries (Allen et al., 1977), sewage (Varma et al., 1976) and sediments (Timoney et al., 1978; Marques et al., 1979).

The mechanism of heavy metal resistance is found to enhance the antibiotic resistance ability of microorganisms (Davidson et al., 1999).The combined expression of metal tolerance and antibiotic 
M. Sharma and H.P. Thapaliya / Our Nature (2009) 7: 203-206

resistance is caused by selection resulting from the metals present in the environment (Nakahara et al., 1977). The presence of a high concentration of metal ions in natural or other settings serve as a selective environment favoring metal resistant bacteria.

The resistant to antibiotics and heavy metal are found to be plasmid mediated. The genetic determinant responsible for the heavy metal resistance often resides on plasmids which mediate antibiotic resistance. Most heavy metals are metabolically poisonous in low concentration. They inhibit the activities of certain enzymes involved in the metabolic processes (Madigan and Martinko, 2006).

The purpose of this study was to determine the antibiotic resistance profile of heavy metal resistant bacterial isolates from the effluent of a garment industry located in Imadole, Lalitpur, Nepal.

\section{Materials and Methods \\ Sample collection}

The samplings were done from the sewage discharge site of a garment industry in Imadol, Lalitpur. The samples were collected in sterile plastic bottles from the site.

Isolation of heavy metal resistance bacteria Four effluent samples collected from the industrial site were plated in nutrient agar plates with different concentration of heavy metals viz., zinc (200 ppm), lead (800 ppm), copper (200 ppm) and aluminum (200 ppm). Four different isolates were selected from each plate, on the basis of the differences in colony morphology for each metal. The identification was done by staining and different biochemical tests.

\section{Antibiotic susceptibility testing}

The antibiotic resistance patterns were determined according to the Kirby-Bauer disc diffusion method. The antibiotics employed were Penicillin (10I.U), Tetracycline $(30 \mathrm{mcg})$, Erythromycin (15 $\mathrm{mcg}$ ), Chloramphenicol (30 mcg), Gentamicin (10 mcg), Cotrimoxazole (25 $\mathrm{mcg}$ ) and Vancomycin (30 mcg).

\section{Results}

The metal tolerant bacteria demonstrated resistance to antibiotics including Penicillin, Erythromycin, Vancomycin, Cotrimoxazole and to a small level towards Chloramphenicol and Tetracycline. No resistance was observed towards Gentamicin as depicted in the Table 1 and Table 2.

Strains isolated in copper showed resistance towards Penicillin, Chloramphenicol, Vancomycin, Cotrimoxazole and intermediately sensitive to erythromycin. Strains in lead showed resistance towards Penicillin, Tetracycline, Erythromycin, Vancomycin, Cotrimoxazole and intermediately sensitive to Chloramphenicol. Zinc tolerant strains showed resistance towards Penicillin, Erythromycin, Vancomycin and intermediately sensitive to Cotrimoxazole. Finally aluminum tolerant bacteria were found to be resistance towards Penicillin, Tetracycline and Erythromycin.

Most of the metal tolerant strains were reported resistant towards one or more antibiotics indicating possible association between metal tolerance and antibiotic resistance.

Among the isolated metal tolerant strains Bacillus spp and Corynebacterium spp were the leading. The second most occurring was 
M. Sharma and H.P. Thapaliya / Our Nature (2009) 7: 203-206

Table 1. Distribution of antibiotic resistance pattern.

\begin{tabular}{llllllllll}
\hline Resistant & \multirow{2}{*}{ Genus } & \multirow{2}{*}{ Heavy metal } & \multicolumn{6}{c}{ Antibiotic Resistance Pattern } \\
\cline { 5 - 9 } & & & P & T & E & C & G & V & Co \\
\hline $\mathrm{Cu}-1$ & Bacillus & Copper & $\mathrm{R}$ & $\mathrm{S}$ & $\mathrm{S}$ & $\mathrm{S}$ & $\mathrm{S}$ & $\mathrm{S}$ & $\mathrm{S}$ \\
$\mathrm{Cu}-2$ & Corynebacterium & Copper & $\mathrm{R}$ & $\mathrm{S}$ & $\mathrm{I}$ & $\mathrm{S}$ & $\mathrm{S}$ & $\mathrm{R}$ & $\mathrm{S}$ \\
$\mathrm{Cu}-3$ & Lactobacillus & Copper & $\mathrm{R}$ & $\mathrm{S}$ & $\mathrm{I}$ & $\mathrm{R}$ & $\mathrm{S}$ & $\mathrm{R}$ & $\mathrm{S}$ \\
$\mathrm{Cu}-4$ & Enterococcus & Copper & $\mathrm{R}$ & $\mathrm{S}$ & $\mathrm{S}$ & $\mathrm{S}$ & $\mathrm{S}$ & $\mathrm{S}$ & $\mathrm{R}$ \\
$\mathrm{Pb}-1$ & Bacillus & Lead & $\mathrm{R}$ & $\mathrm{R}$ & $\mathrm{S}$ & $\mathrm{S}$ & $\mathrm{S}$ & $\mathrm{S}$ & $\mathrm{S}$ \\
$\mathrm{Pb}-2$ & Bacillus & Lead & $\mathrm{R}$ & $\mathrm{S}$ & $\mathrm{R}$ & $\mathrm{I}$ & $\mathrm{S}$ & $\mathrm{S}$ & $\mathrm{R}$ \\
$\mathrm{Pb}-3$ & Corynebacterium & Lead & $\mathrm{R}$ & $\mathrm{S}$ & $\mathrm{S}$ & $\mathrm{S}$ & $\mathrm{S}$ & $\mathrm{R}$ & $\mathrm{S}$ \\
$\mathrm{Pb}-4$ & Lactobacillus & Lead & $\mathrm{I}$ & $\mathrm{S}$ & $\mathrm{S}$ & $\mathrm{S}$ & $\mathrm{S}$ & $\mathrm{S}$ & $\mathrm{R}$ \\
$\mathrm{Zn}-1$ & Aeromonas & Zinc & $\mathrm{R}$ & $\mathrm{S}$ & $\mathrm{R}$ & $\mathrm{S}$ & $\mathrm{S}$ & $\mathrm{R}$ & $\mathrm{S}$ \\
$\mathrm{Zn}-2$ & Corynebacterium & Zinc & $\mathrm{R}$ & $\mathrm{S}$ & $\mathrm{S}$ & $\mathrm{S}$ & $\mathrm{S}$ & $\mathrm{S}$ & $\mathrm{I}$ \\
$\mathrm{Zn}-3$ & Bacillus & Zinc & $\mathrm{R}$ & $\mathrm{S}$ & $\mathrm{I}$ & $\mathrm{S}$ & $\mathrm{S}$ & $\mathrm{S}$ & $\mathrm{S}$ \\
$\mathrm{Zn}-4$ & Corynebacterium & Zinc & $\mathrm{R}$ & $\mathrm{S}$ & $\mathrm{S}$ & $\mathrm{S}$ & $\mathrm{S}$ & $\mathrm{S}$ & $\mathrm{S}$ \\
$\mathrm{Al}-1$ & Corynebacterium & Aluminum & $\mathrm{I}$ & $\mathrm{R}$ & $\mathrm{S}$ & $\mathrm{S}$ & $\mathrm{S}$ & $\mathrm{S}$ & $\mathrm{S}$ \\
$\mathrm{Al}-2$ & Corynebacterium & Aluminum & $\mathrm{R}$ & $\mathrm{S}$ & $\mathrm{S}$ & $\mathrm{S}$ & $\mathrm{S}$ & $\mathrm{S}$ & $\mathrm{S}$ \\
$\mathrm{Al}-3$ & Bacillus & Aluminum & $\mathrm{I}$ & $\mathrm{S}$ & $\mathrm{R}$ & $\mathrm{S}$ & $\mathrm{S}$ & $\mathrm{S}$ & $\mathrm{S}$ \\
$\mathrm{Al}-4$ & Bacillus & Aluminum & $\mathrm{S}$ & $\mathrm{S}$ & $\mathrm{R}$ & $\mathrm{S}$ & $\mathrm{S}$ & $\mathrm{S}$ & $\mathrm{S}$
\end{tabular}

$\mathrm{P}=$ Penicillin, $\mathrm{T}=$ Tetracycline, $\mathrm{E}=$ Erythromycin, $\mathrm{C}=$ Chloramphenicol, $\mathrm{G}=$ Gentamic in, $\mathrm{V}=$ Vancomycin, $\mathrm{Co}=$ Cotrimoxazole, $\mathrm{R}=$ Resistance, $\mathrm{I}=$ Intermed iate, $\mathrm{S}=$ Sensitive

Table 2. Percentage of isolates resistance to antibiotics

\begin{tabular}{lllllllll}
\hline \multirow{2}{*}{ Isolation medium } & $\begin{array}{l}\text { No. of Strains } \\
\text { Examined }\end{array}$ & \multicolumn{7}{c}{ \% Isolates Resistance to Antibiotics } \\
\cline { 3 - 8 } & $\mathbf{P}$ & $\mathbf{T}$ & $\mathbf{E}$ & $\mathbf{C}$ & $\mathbf{G}$ & $\mathbf{V}$ & $\mathbf{C o}$ \\
\hline Copper & 4 & 100 & 0 & $(50)$ & 25 & 0 & 50 & 25 \\
Lead & 4 & $75(25)$ & 25 & 25 & $(25)$ & 0 & 25 & 50 \\
Zinc & 4 & 100 & 0 & $25(25)$ & 0 & 0 & 25 & $(25)$ \\
Aluminum & 4 & $25(50)$ & 25 & 50 & 0 & 0 & 0 & 0 \\
\hline & & & & & & & &
\end{tabular}

Note: ( ) for intermed iately sensitive.

Lactobacillus spp. which was two in number. The rest isolates were Aeromonas spp and Enterococcus spp, one each.

The pattern of antibiotics resistance is shown in Table 1.

\section{Discussion}

In the polluted sites bacteria are continuously exposed to different heavy metals, thus giving rise to survival of the metal tolerant. Even most of the strains which are not metal tolerant becomes tolerant due to mutations. Thus these strains assist in natural transformation leading to the increased incidence of metal tolerant strains in such environment and also dissemination to atmosphere.

The combined expression of metal tolerance and antibiotic resistance is caused by selection resulting from the metals present in the environment (Nakahara et al., 1977).

The genes that code for antibiotic resistance traits and genes that code for metal resistance are often carried on the same plasmid or mobile genetic elements 
M. Sharma and H.P. Thapaliya / Our Nature (2009) 7: 203-206

(Wireman et al., 1997; Yurieva et al., 1997). This shows that there is a close association between metal resistance and antibiotic resistance.

The potential impact of increased antibiotic resistance due to metal contamination is particularly great considering the very large number of metal contaminated locations. Once the bacteria get entered in the atmosphere, the bacteria and their genes get distributed worldwide.

Thus, our attempt is to suggest that the potential impact of metal polluted locations in human life may be much greater than the direct effect of the pollution. Regular surveillance of the effluent in industrial sites is a must if the risk of disease due to such antibiotic resistant organisms is to be avoided.

\section{Acknowledgements}

We like to thank the college management committee of St. Xavier's College, Kathmandu, for the laboratory facilities. Special thanks to our Principal Rev. A. Antonysamy S.J. and all the colleagues of the Department of Microbiology, St. Xavier's College.

\section{References}

Allen, D.A., B. Austin and R.R. Colwell 1977. Antibiotic resistance patterns of metal-tolerant bacteria isolated from an estuary. Antimicrobial Agents and Chemotherapy 12: 545-547.

Davidson, J. 1999. Genetic exchange between bacteria in the environment. Plasmid 42: 73-91.
Madigan, M.T. and J.M. Martinko 2006. Microbial ecology. Brock biology of microorganisms. Prentice Hall Inc.; Upper Saddle River, NJ 07458.USA. pp. 650-651.

Marques, A.M., F. Congregado and D.M. SimonPujol 1979. Antibiotic and heavy metal resistance of Pseudoinonas aeruiiginosa isolated from soils. $J$. Appl. Bacteriol. 47: 347-350.

McHugh, G.L., C.C. Hopkins, R.C. Moellering and M.N. Swartz 1975. Sallmonella typhimurium resistant to silver nitrate, chloramphenicol and ampicillin. Lancet 2: 235-240.

Moten, A.M. and A. Rehman 1998. Study on heavy trace metal ion in industrial waste effluents in Pakistan. environmental-expert.com, article-909.

Nakahara, H., T. Ishikawa, Y. Sarai and I. Kondo 1977. Frequency of heavy-metal resistance in bacteria from inpatients in Japan. Nature (London) 266: 165-167.

Nakahara, H., T. Ishikawa, Y. Sarai, I. Kondo, H. Kozukue and S. Silver 1977. Linkage of mercury, cadmium and arsenate and drug resistance in clinical isolates of Pseudomnoiais aeruiginosa. Appl. Environ. Microbiol. 33: 975-976.

Timoney, J.F., J. Port, J. Giles and J. Spanier 1978. Heavymetal and antibiotic resistance in the bacterial flora of sediments of New York Bight. Appl. Environ. Microbiol. 36: 465-472.

Varma, M.M., W.A. Thomas and C. Prasad 1976. Resistance to inorganic salts and antibiotics among sewage-borne enterobacteriaceae and achromobacteriaceae. J. Appl. Bacteriol. 41: $347-$ 349.

Wireman, J., C.A. Liebert, T. Smith and A.O. Summers 1997. Association of mercury resistance with antibiotic resistance in gram negative fecal bacteria of primates. Appl. Environ. Microbiol. 63: 4494-4503.

Yurieva, O., G. Kholodii, L. Minakhin, Z. Gorlenko, E. Kalyaeva, S. Mindlin and V. Nikiforov 1997. Intercontinental spread of promiscuous mercury resistance transposes in environmental bacteria Mol. Microbiol. 24: 321-329. 